\title{
SYNTHESIS AND ANTIBACTERIAL ACTIVITIES OF METAL COMPLEXES OF CEFTIOFUR
}

\author{
Nitin Tandon ${ }^{1}$, Runjhun Tandon ${ }^{1 *}$, Raakhi Gupta ${ }^{2}$ and Neelima Gupta ${ }^{3}$ \\ ${ }^{1}$ Department of Chemistry, School of Physical Sciences, Lovely Professional University, \\ Phagwara (Punjab), India \\ ${ }^{2}$ Department of Chemistry, IIS University Jaipur (Rajasthan), India \\ ${ }^{3}$ Department of Chemistry, University of Rajasthan, Jaipur (Rajasthan), India \\ *E-mail: gupta.runjhun@gmail.com
}

\begin{abstract}
The objective of the present study is to prepare a family of new monoanionic tridentate Ceftiofur metal complexes $[\mathrm{M}($ Ceftiofur $) \mathrm{Cl}] \cdot \mathrm{xH}_{2} \mathrm{O}$, where $\mathrm{M}=\mathrm{Mn}(\mathrm{II}), \mathrm{Ca}(\mathrm{II}), \mathrm{Fe}(\mathrm{III}), \mathrm{Cu}(\mathrm{II}), \mathrm{Zn}(\mathrm{II}), \mathrm{Mg}(\mathrm{II}), \mathrm{Co}(\mathrm{II})$ and $\mathrm{Ni}(\mathrm{II})$ and to characterize them by different physiochemical techniques. These Ceftiofur metal complexes are further screened for biological activities. Several physiochemical and spectroscopic methods like UV-Vis, ${ }^{1} \mathrm{H}-\mathrm{NMR}$, IR, elemental analysis, and Karl-Fischer titration were used to find out the actual stoichiometry and binding mode of these complexes. The complexes synthesized were subjected to anti-microbial activities using gram-positive as well as gram-negative strains. The chosen strains are Staphylococcus aureus (MTCC87), Bacillus subtilis (MTCC441), Escherichia coli (MTCC40), Proteus vulgaris (MTCC426), Pseudomonas aeuruginosa (MTCC2488), Bacillus cerus (MTCC430), Salmonella typhimurium (MTCC1253). The solubility of Ceftiofur hydrochloride was remarkably decreased in most of the commonly used solvents on its complexation with metal ions under study. The stoichiometric study of these synthesized complexes revealed 1:1 ratio of ligand to metal binding. Ceftiofur showed that on complexation the antibacterial study was affected. The $\mathrm{Cu}^{2+}$ and $\mathrm{Co}^{2+}$ complexes against Pseudomonas aeuruginosaand $\mathrm{Co}^{2+}, \mathrm{Mg}^{2+}$ and $\mathrm{Ni}^{2+}$ complexes againstSalmonella typhimurium showed the highest antibacterial activity, whereas $\mathrm{Ca}^{2+}$ complex showed the highest activity against Proteus vulgaris. Majority of the bacterial strains were found to be resistant to the complexes of $\mathrm{Fe}^{3+}$ and $\mathrm{Zn}^{2+}$.
\end{abstract}

Keywords: ceftiofur hydrochloride, antibiotic, metal complexes, antibacterial activity

○ RASĀYAN. All rights reserved

INTRODUCTION
Ceftiofur hydrochloride (Fig.-1) is a $3^{\text {rd }}$ generation cephalosporin antibiotic showing activity against gram-positive as well as gram-negative microorganisms. ${ }^{1}$ Its antibacterial activities result from the inhibition of muco-peptide synthesis in the cell wall in a fashion similar to that of other cephalosporins. Ceftiofur hydrochloride has worldwide approval for respiratory diseases in ruminants (cattle, sheep and goats) as well as swine, horses and has further been approved for foot rot and metritis infections of cattle. It has also been approved and used in various countries for early mortality infections in turkey poults and day-old chicks. Many drugs have shown a marked increase in toxicological and pharmacological properties when they form a metal complex. The most experimented metal is copper (II) which has proved beneficial in diseases like tuberculosis, rheumatoid arthritis, gastric ulcers, as well as cancers. ${ }^{2-5}$ Cephalosporin antibiotics have been known to behave as a potent chelating agent. ${ }^{6-8}$ Due to the presence of empty d orbitals, transition metal ions can act as Lewis acid catalysts. ${ }^{9}$ The cephalosporin metal complexes have been analyzed by various spectral, thermal voltammetric and by HPLC methods. ${ }^{10-13} \mathrm{~A}$ large number of reports on the effect of chelation on the biological activity of cephalosporin antibiotics ${ }^{14-}$

${ }^{22}$ have appeared in the literature. In several cases, the results were found to be encouraging while in other cases, the activity was only comparable or somewhat lower. In view of these observations, it is required to have more studies using a variety of cephalosporin complexes and a variety of bacterial strains. This

Rasayan J. Chem., 11(4), 1715-1720(2018) http://dx.doi.org/10.31788/RJC.2018.1144049

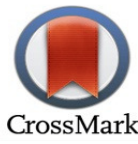


prompted to investigate and synthesize the coordination capacity of Ceftiofur with essential as well as trace metal ions and screen them for biological activity. The results of the synthesis, characterization along with the biological activity of metal complexes of Ceftiofur are reported herein.

\section{EXPERIMENTAL}

The chemicals used were of pharma grade and were taken without any purification. The solvents were dried and distilled by standard techniques available before use. Ceftiofur hydrochloride was obtained from Macleods Pharmaceuticals, Mumbai, India as gratis. Commercially available metal salts were used as such.

The complexes were synthesized by mixing metal salts $\mathrm{MnCl}_{2} \cdot 2 \mathrm{H}_{2} \mathrm{O}, \mathrm{ZnCl}_{2}, \mathrm{CoCl}_{2} \cdot 6 \mathrm{H}_{2} \mathrm{O}, \mathrm{NiCl}_{2} \cdot 6 \mathrm{H}_{2} \mathrm{O}$, $\mathrm{CuCl}_{2} \cdot 2 \mathrm{H}_{2} \mathrm{O}, \mathrm{FeCl}_{3}, \mathrm{CaCl}_{2}, \mathrm{MgCl}_{2} \cdot 6 \mathrm{H}_{2} \mathrm{O}(1 \mathrm{mmol})$ to a solution of Ceftiofur hydrochloride $(1 \mathrm{mmol})$ in Methanol $(40 \mathrm{ml})$ under $\left(\mathrm{N}_{2}\right)$ nitrogen atmosphere. The reaction mixture was stirred at 25-30 $\mathrm{C}$ for 1 hour. The volume was further reduced by rotary evaporation. The complexes which precipitated with time were filtered off, rinsed with water, methanol and diisopropyl ether, and dried in vacuum oven at room temperature.

\section{Antibacterial Activity Test}

The anti-bacterial activities of Ceftiofur hydrochloride and its metal complexes were studied by the disk diffusion method. ${ }^{23}$ The bacterial strains, Staphylococcus aureus (MTCC87), Bacillus subtilis (MTCC441), Escherichia coli (MTCC40), Proteus vulgaris (MTCC426), Pseudomonas aeuruginosa (MTCC2488), Bacillus cerus (MTCC430), Salmonella typhimurium (MTCC1253), chosen for studies were procured from Microbial Type Culture Collection and Gene Bank (MTCC), Chandigarh, India. A loop full of bacterial culture was inoculated into sterilized tryptone soya broth and incubated at $37^{\circ} \mathrm{C}$ for 16-18 hours. A sterilized cotton was dipped into standardized bacterial test suspension and was used to evenly inoculate the entire surface of mullar Hinton agar plate. The disc of Ceftiofur hydrochloride and its metal complexes were dipped in the test solutions prepared in methanol $(12 \mu \mathrm{g} / \mathrm{ml}$ and $32 \mu \mathrm{g} / \mathrm{ml})$ and placed onto the surface of mullar Hinton agar plate with sterilized forceps. After 20-24 hours of incubation, along with the diameter of the zone of inhibition around the disc were measured.

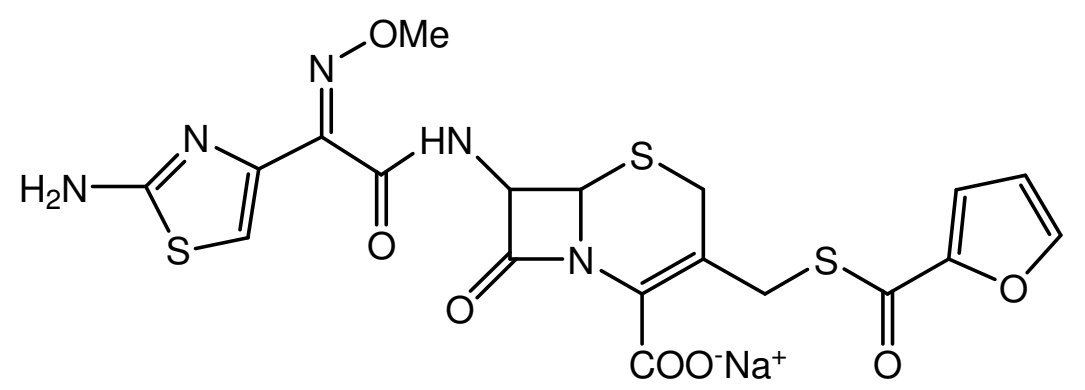

Fig.-1: Ceftiofur Hydrochloride

\section{Physicochemical and Spectroscopic Characterization \\ FT-IR Spectroscopy}

The infrared spectra of Ceftiofur hydrochloride and its metal complexes were recorded using an FT-IR spectrometer Nicolet Protégé 460 on potassium bromide pellets in the range from 400 to $4000 \mathrm{~cm}^{-1}$.

\section{UV-Vis Spectroscopy}

A UV-Vis spectrum was taken on Perkin Elmer's (Lambda 3B) spectrophotometer. All the spectra were recorded in DMSO.

\section{Elemental Analysis}

Carbon, Hydrogen, Sulphur and Nitrogen contents were analyzed using Thermo Electron Corporation Flash EA 1112 analyzer. 
RASĀYAN $J$. Chem.

Vol. 11 | No. 4 |1715 - 1720| October - December | 2018

\section{Water Content Determination}

Moisture content in the synthesized complexes was analyzed on the Karl-Fischer-Titrator $\mu$ Aqua Cal 50 instrument.

\section{${ }^{1}$ H NMR}

NMR spectroscopic proton measurements were done on Bruker $300 \mathrm{MHz}$ and JEOL JNM $300 \mathrm{MHz}$, using TMS as an internal reference along with deuterated DMSO as solvent (Table-4).

\section{RESULTS AND DISCUSSION}

The metal complexes from Ceftiofur hydrochloride were obtained as air stable colored solids (Table-1). Elemental analysis (Table-1) data suggested the formation of 1:1 metal-ligand complex. All the metal complexes were either insoluble or very less soluble in most of the organic solvents except in DMSO.

Moisture analysis by Karl-Fischer titrations of Ceftiofur hydrochloride and its metal complexes indicated the presence of 3-6 molecules of water of crystallization (Table-1). The UV analysis of the metal complexes revealed that there was no significant change in the spectra of synthesized metal complexes and its parent Ceftiofur hydrochloride. The IR spectra of Ceftiofur hydrochloride and their metal complexes exhibited a number of characteristic bands (Table-2). The solubility of Ceftiofur hydrochloride changed drastically on its complexation with the metal ions under study which is in consonance with the results reported earlier for the complexes of other cephalosporins. ${ }^{22}$ In conformity with the result of cefpodizime, ${ }^{22}$ there was no significant change in the UV spectra of metal complexes from Ceftiofur hydrochloride.

Table-1: Color, Elemental Analysis and Moisture Content of Ceftiofur Metal Complexes; Found (Calculated)

\begin{tabular}{c|c|c|c|c|c|c}
\hline \multirow{2}{*}{ Compound } & \multirow{2}{*}{ Color } & \multicolumn{3}{|c|}{ Elemental Analysis (\%) } & Moisture \\
\cline { 3 - 6 } & & $\mathrm{C}$ & $\mathrm{H}$ & $\mathrm{N}$ & $\mathrm{S}$ & Content (\%) \\
\hline $\mathrm{C}_{19} \mathrm{H}_{16} \mathrm{~N}_{5} \mathrm{O}_{7} \mathrm{~S}_{3} \mathrm{Na}$ & Pale Yellow & $41.8(41.8)$ & $2.9(3.0)$ & $12.1(12.8)$ & $17.8(17.6)$ & $0.1(0.0)$ \\
\hline$\left[\mathrm{Mn}\left(\mathrm{C}_{19} \mathrm{H}_{16} \mathrm{~N}_{5} \mathrm{O}_{7} \mathrm{~S}_{3}\right) \mathrm{Cl}\right] .3 \mathrm{H}_{2} \mathrm{O}$ & Light yellow & $34.3(34.2)$ & $3.3(3.3)$ & $11.0(10.5)$ & $14.8(14.4)$ & $8.2(8.1)$ \\
\hline$\left[\mathrm{Ca}\left(\mathrm{C}_{19} \mathrm{H}_{16} \mathrm{~N}_{5} \mathrm{O}_{7} \mathrm{~S}_{3}\right) \mathrm{Cl}\right] .6 \mathrm{H}_{2} \mathrm{O}$ & Orange & $32.3(32.3)$ & $4.1(4.0)$ & $10.1(9.9)$ & $13.3(13.6)$ & $15.7(15.2)$ \\
\hline$\left[\mathrm{Fe}\left(\mathrm{C}_{19} \mathrm{H}_{16} \mathrm{~N}_{5} \mathrm{O}_{7} \mathrm{~S}_{3}\right) \mathrm{Cl}_{2}\right] .6 \mathrm{H}_{2} \mathrm{O}$ & Dirty green & $30.4(30.1)$ & $3.6(3.7)$ & $9.7(9.2)$ & $12.3(12.7)$ & $14.5(14.2)$ \\
\hline$\left[\mathrm{Cu}\left(\mathrm{C}_{19} \mathrm{H}_{16} \mathrm{~N}_{5} \mathrm{O}_{7} \mathrm{~S}_{3}\right) \mathrm{Cl}\right] .3 \mathrm{H}_{2} \mathrm{O}$ & Dark green & $33.2(33.7)$ & $3.1(3.3)$ & $10.7(10.3)$ & $13.6(14.2)$ & $8.3(8.0)$ \\
\hline$\left[\mathrm{Zn}\left(\mathrm{C}_{19} \mathrm{H}_{16} \mathrm{~N}_{5} \mathrm{O}_{7} \mathrm{~S}_{3}\right) \mathrm{Cl}\right] .3 \mathrm{H}_{2} \mathrm{O}$ & Off white & $34.1(33.7)$ & $3.8(3.3)$ & $10.7(10.3)$ & $15.0(14.2)$ & $8.7(7.9)$ \\
\hline$\left[\mathrm{Mg}\left(\mathrm{C}_{19} \mathrm{H}_{16} \mathrm{~N}_{5} \mathrm{O}_{7} \mathrm{~S}_{3}\right) \mathrm{Cl}\right] .6 \mathrm{H}_{2} \mathrm{O}$ & Dark yellow & $33.5(33.1)$ & $4.6(4.1)$ & $10.2(10.1)$ & $14.2(13.9)$ & $15.8(15.6)$ \\
\hline$\left[\mathrm{Co}\left(\mathrm{C}_{19} \mathrm{H}_{16} \mathrm{~N}_{5} \mathrm{O}_{7} \mathrm{~S}_{3}\right) \mathrm{Cl}\right] .3 \mathrm{H}_{2} \mathrm{O}$ & Light pink & $34.4(34.0)$ & $3.0(3.3)$ & $10.1(10.4)$ & $14.8(14.3)$ & $8.4(8.0)$ \\
\hline$\left[\mathrm{Ni}\left(\mathrm{C}_{19} \mathrm{H}_{16} \mathrm{~N}_{5} \mathrm{O}_{7} \mathrm{~S}_{3}\right) \mathrm{Cl}\right] .4 \mathrm{H}_{2} \mathrm{O}$ & Green & $33.9(33.1)$ & $3.4(3.5)$ & $10.7(10.2)$ & $14.3(13.9)$ & $10.9(10.5)$ \\
\hline
\end{tabular}

In case of IR spectrum it is found that compared to the characteristic band at $1764 \mathrm{~cm}^{-1}$ and $1606 \mathrm{~cm}^{-1}$ in case of Ceftiofur hydrochloride corresponding to the stretching frequency of the -lactam carbonyl (CO) group and the amidic carbonyl group, respectively, in metal complexes they appeared in the range of 1743-1777 $\mathrm{cm}^{-1}$ and $1635-1667 \mathrm{~cm}^{-1}$,respectively. The change in the shifts of the amidic carbonyl group by $29-61 \mathrm{~cm}^{-1}$, in most of the cases, suggested that the coordination to the metal occurred through the carbonyl oxygen of the amidic bond rather than the -lactam carbonyl group. A similar observation has been made earlier in the case of cefazolin. ${ }^{20}$

In the cases of $\mathrm{Fe}^{3+}$ and $\mathrm{Cu}^{2+}$ complexes, however slight change in the range of $13-21 \mathrm{~cm}^{-1}$ corresponding to -lactamic group indicated the possibility of the bonding of metal ion with -lactamic carbonyl oxygen as well. In the case of cephalothin, a shift in the range of $40-60 \mathrm{~cm}^{-1}$ has been attributed to -lactamic carbonyl group ${ }^{14}$ However, in the case of $\mathrm{Mg}^{2+}$ complexes, the band for the -lactam carbonyl group disappeared. The difference between the symmetric and asymmetric vibration values of carboxylate group was more than 200 in all the synthesized metal complexes, suggesting that the carboxylate group was binding as monodentate ligand ${ }^{24}$ except in the case of $\mathrm{Fe}^{3+}$ and $\mathrm{Mg}^{2+}$ where the band corresponding to $v(\mathrm{COO})$ symmetric and $v(\mathrm{COO})$ asymmetric disappeared respectively. ${ }^{19}$ Insignificant change in the stretching vibration due to the C-S bond as compared to Ceftiofur hydrochloride $\left(1036 \mathrm{~cm}^{-1}\right)$ suggested that this group did not bind to metal ions. Analogously, C-N stretching frequency did not change as compared to Ceftiofur hydrochloride $\left(1385 \mathrm{~cm}^{-1}\right)$ indicating the -lactam nitrogen and thiazole nitrogen did 
RASĀYAN J. Chem.

Vol. 11 | No. 4 |1715 - 1720| October - December | 2018

not coordinate to metal ions. The appearance of new bands at $410-450 \mathrm{~cm}^{-1}$ in all the complexes may be attributed to M-N stretching vibrations arising due to the bonding of metal ion with the amino group of thiazole ring, ${ }^{25}$ The other possible binding site from $\mathrm{C}=\mathrm{N}-\mathrm{OCH}_{3}$ group being sterically unavailable. ${ }^{14} \mathrm{In}$ accordance with the results reported earlier in literature ${ }^{14,15}$ except for $\mathrm{Zn}^{2+}$ and $\mathrm{Ca}^{2+}$, the ${ }^{1} \mathrm{H}-\mathrm{NMR}$ spectra of Ceftiofur metal complexes gave broad unresolved signals.

Table-2: Some important FT-IR Spectral Signals (in $\mathrm{cm}^{-1}$ ) of Ceftiofur Hydrochloride and its Metal Complexes

\begin{tabular}{c|c|c|c|c|c}
\hline Compound & $\begin{array}{c}\mathrm{C}=\mathrm{O} \\
\text { (Amide) }\end{array}$ & $\begin{array}{c}\mathrm{C}=\mathrm{O} \\
(\mathrm{Lactam})\end{array}$ & $\begin{array}{c}v(\mathrm{COO}) \\
\text { Symmetric }\end{array}$ & $\begin{array}{c}v(\mathrm{COO}) \\
\text { Asymmetric }\end{array}$ & $\Delta v(\mathrm{COO})$ \\
\hline $\mathrm{C}_{19} \mathrm{H}_{16} \mathrm{~N}_{5} \mathrm{O}_{7} \mathrm{~S}_{3} \mathrm{Na}$ & 1601 & 1764 & 1359 & 1565 & 206 \\
\hline$\left[\mathrm{Mn}\left(\mathrm{C}_{19} \mathrm{H}_{16} \mathrm{~N}_{5} \mathrm{O}_{7} \mathrm{~S}_{3}\right) \mathrm{Cl}\right] .3 \mathrm{H}_{2} \mathrm{O}$ & 1635 & 1766 & 1358 & 1558 & 200 \\
\hline$\left[\mathrm{Ca}\left(\mathrm{C}_{19} \mathrm{H}_{16} \mathrm{~N}_{5} \mathrm{O}_{7} \mathrm{~S}_{3}\right) \mathrm{Cl}\right] .6 \mathrm{H}_{2} \mathrm{O}$ & 1656 & 1758 & 1364 & 1594 & 230 \\
\hline$\left[\mathrm{Fe}\left(\mathrm{C}_{19} \mathrm{H}_{16} \mathrm{~N}_{5} \mathrm{O}_{7} \mathrm{~S}_{3}\right) \mathrm{Cl}_{2}\right] .6 \mathrm{H}_{2} \mathrm{O}$ & 1640 & 1743 & --- & 1564 & --- \\
\hline$\left[\mathrm{Cu}\left(\mathrm{C}_{19} \mathrm{H}_{16} \mathrm{~N}_{5} \mathrm{O}_{7} \mathrm{~S}_{3}\right) \mathrm{Cl}\right] \cdot 3 \mathrm{H}_{2} \mathrm{O}$ & 1667 & 1777 & 1364 & 1579 & 215 \\
\hline$\left[\mathrm{Zn}\left(\mathrm{C}_{19} \mathrm{H}_{16} \mathrm{~N}_{5} \mathrm{O}_{7} \mathrm{~S}_{3}\right) \mathrm{Cl}\right] .3 \mathrm{H}_{2} \mathrm{O}$ & 1635 & 1768 & 1354 & 1558 & 204 \\
\hline$\left[\mathrm{Mg}\left(\mathrm{C}_{19} \mathrm{H}_{16} \mathrm{~N}_{5} \mathrm{O}_{7} \mathrm{~S}_{3}\right) \mathrm{Cl}\right] \cdot 6 \mathrm{H}_{2} \mathrm{O}$ & 1645 & Disappeared & 1345 & --- & --- \\
\hline$\left[\mathrm{Co}\left(\mathrm{C}_{19} \mathrm{H}_{16} \mathrm{~N}_{5} \mathrm{O}_{7} \mathrm{~S}_{3}\right) \mathrm{Cl}\right] .3 \mathrm{H}_{2} \mathrm{O}$ & 1632 & 1767 & 1354 & 1575 & 221 \\
\hline$\left[\mathrm{Ni}\left(\mathrm{C}_{19} \mathrm{H}_{16} \mathrm{~N}_{5} \mathrm{O}_{7} \mathrm{~S}_{3}\right) \mathrm{Cl}\right] .4 \mathrm{H}_{2} \mathrm{O}$ & 1626 & 1766 & 1365 & 1598 & 233 \\
\hline
\end{tabular}

The NMR spectra of $\mathrm{Mn}$ (II) and Co(II) complexes could not be recorded due to the insolubility of these complexes in DMSO-d6. As compared to ceftiofur sodium and other metal complexes, in the case of $\mathrm{Zn}$ (II) complex the peak due to -OMe group appears slightly down the field at $\delta 3.94$. Cepham S-CH2 protons appear as a broad signal in ceftiofur sodium and its metal complexes in contrast to two individual peaks observed in the NMR spectra of ceftiofur free acid. The peak corresponding to these protons appears $\sim \delta 4.1$ in ceftiofur sodium and its $\mathrm{Ca}(\mathrm{II})$ and $\mathrm{Zn}$ (II) complexes and at $\delta 3.69$ in $\mathrm{Fe}$ (III) complex. In the spectra of $\mathrm{Ni}(\mathrm{II}), \mathrm{Cu}(\mathrm{II})$ and $\mathrm{Mg}$ (II) complexes, the peak corresponding to these protons was not observed probably due to overlapping by the solvent signal.

The S-CH2 protons at position 3 of cepham moiety appear as broad peak near $\delta 2.16$. The 6-CH and 7-CH protons appear at $\delta 5.00$ and $\delta 5.59$, respectively as a broad signal in case of ceftiofur sodium and there is no appreciable change in the $\delta$ values of these protons in all complexes except that they get further broadened. Compared to the two peaks at $\delta 6.95$ and 6.63, corresponding to thiazole 4"-CH and furan 4'$\mathrm{CH}$ protons respectively in ceftiofur free acid. $\mathrm{In} \mathrm{Cu}(\mathrm{II})$ complex, these protons appear at $\delta 7.08$ and 6.89. However, in the case, ceftiofur sodium and all other metal complexes these protons merge to give broad signal near $\delta 6.7$. The amino group at position 2" of thiazole moiety and furan 3'-CH protons appear at $\delta$ 7.23 and 7.39 respectively in case of ceftiofur sodium. Although the peaks corresponding to these protons appear as a broad signal in the metal complexes, the chemical shift does not change appreciably. As compared to the peak at $\delta 7.74$ due to furan $5^{\prime}-\mathrm{CH}$ in the case of ceftiofur acid, a downfield shift is observed in the case of ceftiofur sodium and its metal complexes near $\delta 8.03$, except in the case of $\mathrm{Zn}$ (II) where the peak appears at 7.79. The signal at $\delta 9.53$ in NMR spectra of ceftiofur sodium due to amidic 7$\mathrm{NH}$ protons do not change significantly in its metal complexes.

\section{Antibacterial Activity}

All the prepared complexes were studied for antibacterial activity against both Gram positive and Gram negative strains. (Table-3). It has been observed that in general $\mathrm{Co}^{2+}$ and $\mathrm{Cu}^{2+}$ complex against Pseudomonas aeruginosa (MTCC2488) and $\mathrm{Co}^{2+}, \mathrm{Mg}^{2+}$ and $\mathrm{Ni}^{2+}$ complexes against Salmonella typhimurium (MTCC1253) show the highest antibacterial activity under test conditions. Previously, similar results were found for $\mathrm{Co}^{2+}$ complex of Ciprofloxacin ${ }^{17}$ which showed better activity against Pseudomonas aeruginosa (ATCC 9027) as well as Salmonella typhimurium (ATCC 14028). $\mathrm{Ca}^{2+}$ and $\mathrm{Mn}^{2+}$ complexes against Proteus vulgaris also showed good antibacterial activity under test conditions. The activity of $\mathrm{Ca}^{2+}$ complex against Bacillus subtilis, of $\mathrm{Mg}^{2+}$ complex against Pseudomonas aeruginosa and of $\mathrm{Zn}^{2+}$ complex against Proteus vulgaris was found to be comparable to the activity of standard Ceftiofur hydrochloride. Majority of bacterial strains were found to be resistant to the complexes of $\mathrm{Fe}^{3+}$ 
RASĀYAN J. Chem.

Vol. 11 | No. 4 |1715 - 1720| October - December | 2018

and $\mathrm{Zn}^{2+}$ and in the remaining cases, the antibacterial activity was somewhat lower as compared to the test standard.

Table-3: Antibacterial Activities of Ceftiofur Metal Complexes showing Zone of Inhibition(in mm)at 12 and 32 $\mu \mathrm{g} / \mathrm{ml}$

\begin{tabular}{|c|c|c|c|c|c|c|c|c|c|c|c|c|c|c|}
\hline \multirow[t]{2}{*}{ Compound } & \multicolumn{2}{|c|}{$\begin{array}{c}\text { MTCC } \\
87\end{array}$} & \multicolumn{2}{|c|}{$\begin{array}{c}\text { MTCC } \\
430\end{array}$} & \multicolumn{2}{|c|}{$\begin{array}{c}\text { MTCC } \\
441\end{array}$} & \multicolumn{2}{|c|}{$\begin{array}{c}\text { MTCC } \\
40\end{array}$} & \multicolumn{2}{|c|}{$\begin{array}{c}\text { MTCC } \\
426\end{array}$} & \multicolumn{2}{|c|}{$\begin{array}{c}\text { MTCC } \\
2488\end{array}$} & \multicolumn{2}{|c|}{$\begin{array}{c}\text { MTCC } \\
1253\end{array}$} \\
\hline & 12 & 32 & 12 & 32 & 12 & 32 & 12 & 32 & 12 & 32 & 12 & 32 & 12 & 32 \\
\hline $\mathrm{C}_{19} \mathrm{H}_{16} \mathrm{~N}_{5} \mathrm{O}_{7} \mathrm{~S}_{3} \mathrm{Na}$ & 28 & 33 & $\mathrm{R}$ & 17 & 18 & 23 & 24 & 27 & 19 & 29 & 17 & 18 & 31 & 49 \\
\hline$\left[\mathrm{Mn}\left(\mathrm{C}_{19} \mathrm{H}_{16} \mathrm{~N}_{5} \mathrm{O}_{7} \mathrm{~S}_{3}\right) \mathrm{Cl}\right] .3 \mathrm{H}_{2} \mathrm{O}$ & 14.3 & 13.6 & 9 & 9.2 & $\mathrm{R}$ & 12 & 10 & 16 & 13 & 30 & $\mathrm{R}$ & $\mathrm{R}$ & 13 & 21 \\
\hline$\left[\mathrm{Ca}\left(\mathrm{C}_{19} \mathrm{H}_{16} \mathrm{~N}_{5} \mathrm{O}_{7} \mathrm{~S}_{3}\right) \mathrm{Cl}\right] .6 \mathrm{H}_{2} \mathrm{O}$ & 8.6 & 8 & 12.3 & 12.5 & 17.6 & 21 & 17.6 & 21 & 20 & 32.3 & $\mathrm{R}$ & $\mathrm{R}$ & $\mathrm{R}$ & 20 \\
\hline$\left[\mathrm{Fe}\left(\mathrm{C}_{19} \mathrm{H}_{16} \mathrm{~N}_{5} \mathrm{O}_{7} \mathrm{~S}_{3}\right) \mathrm{Cl}_{2}\right] .6 \mathrm{H}_{2} \mathrm{O}$ & $\mathrm{R}$ & $\mathrm{R}$ & 10.6 & 10.9 & $\mathrm{R}$ & 8 & $\mathrm{R}$ & $\mathrm{R}$ & $\mathrm{R}$ & 11.6 & $\mathrm{R}$ & $\mathrm{R}$ & $\mathrm{R}$ & $\mathrm{R}$ \\
\hline$\left[\mathrm{Cu}\left(\mathrm{C}_{19} \mathrm{H}_{16} \mathrm{~N}_{5} \mathrm{O}_{7} \mathrm{~S}_{3}\right) \mathrm{Cl}\right] .3 \mathrm{H}_{2} \mathrm{O}$ & 14 & 14 & 14 & 14 & 16 & 17 & 10 & 18 & 12 & 18 & 20 & 22 & 21 & 34 \\
\hline$\left[\mathrm{Zn}\left(\mathrm{C}_{19} \mathrm{H}_{16} \mathrm{~N}_{5} \mathrm{O}_{7} \mathrm{~S}_{3}\right) \mathrm{Cl}\right] .3 \mathrm{H}_{2} \mathrm{O}$ & 11 & 15 & 11.3 & 11.5 & 16.3 & 19.3 & $\mathrm{R}$ & 12 & 20 & 27.3 & $\mathrm{R}$ & $\mathrm{R}$ & $\mathrm{R}$ & 14 \\
\hline 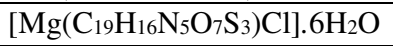 & 12 & 13 & $\mathrm{R}$ & 13 & 13 & 20 & 15 & 20 & 16 & 22 & 17 & 17 & 29 & 35 \\
\hline$\left[\mathrm{Co}\left(\mathrm{C}_{19} \mathrm{H}_{16} \mathrm{~N}_{5} \mathrm{O}_{7} \mathrm{~S}_{3}\right) \mathrm{Cl}\right] .3 \mathrm{H}_{2} \mathrm{O}$ & 18 & 23 & $\mathrm{R}$ & 14 & 14 & 16 & 17 & 17 & 17 & 19 & 18 & 20 & 33 & 34 \\
\hline$\left[\mathrm{Ni}\left(\mathrm{C}_{19} \mathrm{H}_{16} \mathrm{~N}_{5} \mathrm{O}_{7} \mathrm{~S}_{3}\right) \mathrm{Cl}\right] \cdot 4 \mathrm{H}_{2} \mathrm{O}$ & 14 & 22 & $\mathrm{R}$ & 12 & 14 & 15 & 13 & 19 & 15 & 23 & 15 & 18 & 29 & 32 \\
\hline
\end{tabular}

R- resistant; Staphylococcus aureus (MTCC87), Bacillus cerus (MTCC430), Bacillus subtilis (MTCC441), Escherichia coli (MTCC40), Proteus vulgaris (MTCC426), Pseudomonas aeuruginosa (MTCC2488), Salmonella typhimurium (MTCC1253)

Table-4: NMR of Ceftiofur Complexes

\begin{tabular}{|c|c|}
\hline Complex & ${ }^{1} \mathrm{H}-\mathrm{NMR}, \mathrm{DMSO}, \delta \mathrm{ppm}^{\mathrm{a}}$ \\
\hline $\mathrm{C}_{19} \mathrm{H}_{16} \mathrm{~N}_{5} \mathrm{O}_{7} \mathrm{~S}_{3} \mathrm{Na}$ & $\begin{array}{l}\left.3.82(\mathrm{~s}, 3 \mathrm{H},-\mathrm{OMe}), 4.05\left(\mathrm{br}, 2 \mathrm{H}, 2-\mathrm{CH}_{2}\right), 4.16 \text { (unresolved multiplet, } 2 \mathrm{H}, 3-\mathrm{CH}_{2}\right) \text {, } \\
5.00(\mathrm{br}, 1 \mathrm{H}, 6-\mathrm{CH}), 5.59(\mathrm{br}, 1 \mathrm{H}, 7-\mathrm{CH}), 6.72\left(\mathrm{br}, 2 \mathrm{H}, 4 \text { - }-\mathrm{CH}+4^{\prime}-\mathrm{CH}\right), 7.23 \mathrm{br} \text {, } \\
\left.2 \mathrm{H}, 2^{2}-\mathrm{NH}_{2}\right), 7.39\left(\mathrm{br}, 1 \mathrm{H}, 3^{\prime}-\mathrm{CH}\right), 8.03\left(\mathrm{br}, 1 \mathrm{H}, 5^{\prime}-\mathrm{CH}\right), 9.53(\mathrm{br}, 1 \mathrm{H}, 7-\mathrm{NH}) .\end{array}$ \\
\hline$\left[\mathrm{Ca}\left(\mathrm{C}_{19} \mathrm{H}_{16} \mathrm{~N}_{5} \mathrm{O}_{7} \mathrm{~S}_{3}\right) \mathrm{Cl}\right] \cdot 6 \mathrm{H}_{2} \mathrm{O}$ & $\begin{array}{l}\left.3.82(\mathrm{~s}, 3 \mathrm{H},-\mathrm{OMe}), 4.10 \text { (unresolved multiplet, } 2 \mathrm{H}, 2-\mathrm{CH}_{2}\right), 4.20 \text { (unresolved } \\
\left.\text { multiplet, } 2 \mathrm{H}, 3-\mathrm{CH}_{2}\right), 5.04\left(\mathrm{~d}, 1 \mathrm{H}, 6-\mathrm{CH},{ }^{3} \mathrm{~J}_{\mathrm{HH}}=4.76 \mathrm{~Hz}\right), 5.62 \text { (unresolved } \\
\text { multiplet, } 1 \mathrm{H}, 7-\mathrm{CH}), 6.75\left(\mathrm{~m}, 2 \mathrm{H}, 4 "-\mathrm{CH}+4^{\prime}-\mathrm{CH}\right), 7.24\left(\mathrm{br}, 2 \mathrm{H}, 2 "-\mathrm{NH}_{2}\right), 7.40(\mathrm{~d} \text {, } \\
\left.1 \mathrm{H}, 3^{\prime}-\mathrm{CH},{ }^{3} \mathrm{~J}_{\mathrm{HH}}=3.4 \mathrm{~Hz}\right), 8.04\left(\mathrm{~d}, 1 \mathrm{H}, 5^{\prime}-\mathrm{CH},{ }^{3} \mathrm{~J}_{\mathrm{HH}}=1.0 \mathrm{~Hz}\right), 9.56(\mathrm{~d}, 1 \mathrm{H}, 7-\mathrm{NH}, \\
\left.{ }^{3} \mathrm{~J}_{\mathrm{HH}}=8.16 \mathrm{~Hz}\right) .\end{array}$ \\
\hline$\left[\mathrm{Fe}\left(\mathrm{C}_{19} \mathrm{H}_{16} \mathrm{~N}_{5} \mathrm{O}_{7} \mathrm{~S}_{3}\right) \mathrm{Cl}_{2}\right] .6 \mathrm{H}_{2} \mathrm{O}$ & $\begin{array}{l}3.82(\mathrm{br}, 3 \mathrm{H},-\mathrm{OMe}), 5.1(\mathrm{br}, 1 \mathrm{H}, 6-\mathrm{CH}),, 5.7(\mathrm{br}, 1 \mathrm{H}, 7-\mathrm{CH}), 6.66(\mathrm{br}, 2 \mathrm{H}, 4 "-\mathrm{CH}+ \\
\left.\left.4^{\prime}-\mathrm{CH}\right), 7.19\left(\mathrm{br}, 2 \mathrm{H}, 2^{\prime}-\mathrm{NH}_{2}\right), 7.43\left(\mathrm{br}, 1 \mathrm{H}, 3^{\prime}-\mathrm{CH}\right), 8.07 \mathrm{br}, 1 \mathrm{H}, 5^{\prime}-\mathrm{CH}\right) .\end{array}$ \\
\hline$\left[\mathrm{Cu}\left(\mathrm{C}_{19} \mathrm{H}_{16} \mathrm{~N}_{5} \mathrm{O}_{7} \mathrm{~S}_{3}\right) \mathrm{Cl}\right] \cdot 3 \mathrm{H}_{2} \mathrm{O}$ & $\begin{array}{l}3.87(\mathrm{br}, 3 \mathrm{H},-\mathrm{OMe}), 4.1\left(\mathrm{br}, 2 \mathrm{H}, 3-\mathrm{CH}_{2}\right), 5.17(\mathrm{br}, 1 \mathrm{H}, 6-\mathrm{CH}),, 5.89(\mathrm{br}, 1 \mathrm{H}, 7-\mathrm{CH}), \\
6.89\left(\mathrm{~b}, 1 \mathrm{H}, 4^{\prime}-\mathrm{CH}\right), 7.08\left(\mathrm{br}, 1 \mathrm{H}, 4^{\prime}-\mathrm{CH}\right), 7.21\left(\mathrm{br}, 2 \mathrm{H}, 2^{\prime}-\mathrm{NH}_{2}\right), 7.44\left(\mathrm{br}, 1 \mathrm{H}, 3^{\prime}-\right. \\
\mathrm{CH}), 8.05\left(\mathrm{br}, 1 \mathrm{H}, 5^{\prime}-\mathrm{CH}\right) .\end{array}$ \\
\hline$\left[\mathrm{Zn}\left(\mathrm{C}_{19} \mathrm{H}_{16} \mathrm{~N}_{5} \mathrm{O}_{7} \mathrm{~S}_{3}\right) \mathrm{Cl}\right] .3 \mathrm{H}_{2} \mathrm{O}$ & $\begin{array}{l}3.94(\mathrm{~s}, 3 \mathrm{H},-\mathrm{OMe}), 4.1\left(\mathrm{br}, 2 \mathrm{H}, 2-\mathrm{CH}_{2}\right), 4.20\left(\mathrm{br}, 2 \mathrm{H}, 3-\mathrm{CH}_{2}\right), 5.12(\mathrm{br}, 1 \mathrm{H}, 6-\mathrm{CH}) \text {, } \\
5.73(\mathrm{br}, 1 \mathrm{H}, 7-\mathrm{CH}), 6.75\left(\mathrm{~m}, 2 \mathrm{H}, 4{ }^{\prime}-\mathrm{CH}+4^{\prime}-\mathrm{CH}\right), 7.23\left(\mathrm{br}, 2 \mathrm{H}, 2 "-\mathrm{NH}_{2}\right), 7.40 \\
\text { (unresolved multiplet, 1H, 3'-CH), } 7.79\left(\mathrm{~d}, 1 \mathrm{H}, 5^{\prime}-\mathrm{CH},{ }^{3} \mathrm{~J}_{\mathrm{HH}}=1.0 \mathrm{~Hz}\right), 9.59(\mathrm{~d}, 1 \mathrm{H}, 7- \\
\left.\mathrm{NH},{ }^{3} \mathrm{~J}_{\mathrm{HH}}=8.12 \mathrm{~Hz}\right) .\end{array}$ \\
\hline$\left[\mathrm{Mg}\left(\mathrm{C}_{19} \mathrm{H}_{16} \mathrm{~N}_{5} \mathrm{O}_{7} \mathrm{~S}_{3}\right) \mathrm{Cl}\right] \cdot 6 \mathrm{H}_{2} \mathrm{O}$ & $\begin{array}{l}3.82 \text { (unresolved multiplet, 3H, -OMe), } 5.19(\mathrm{br}, 1 \mathrm{H}, 6-\mathrm{CH}), 5.62(\mathrm{br}, 1 \mathrm{H}, 7-\mathrm{CH}) \text {, } \\
\left.6.76 \text { (unresolved multiplet, } 2 \mathrm{H}, 4 "-\mathrm{CH}+4{ }^{\prime}-\mathrm{CH}\right), 7.24 \text { (unresolved multiplet, } 3 \mathrm{H} \text {, } \\
\left.\left.\text { 2"- } \mathrm{NH}_{2}\right), 7.42 \text { (unresolved multiplet, } 1 \mathrm{H}, 3 \text { '- } \mathrm{CH}\right), 8.07 \text { (unresolved multiplet, } 1 \mathrm{H} \text {, } \\
\text { 5'-CH), } 9.55(\mathrm{br}, 1 \mathrm{H}, 7-\mathrm{NH}) \text {. }\end{array}$ \\
\hline$\left[\mathrm{Ni}\left(\mathrm{C}_{19} \mathrm{H}_{16} \mathrm{~N}_{5} \mathrm{O}_{7} \mathrm{~S}_{3}\right) \mathrm{Cl}\right] .4 \mathrm{H}_{2} \mathrm{O}$ & $\begin{array}{l}3.80(\mathrm{~s}, 3 \mathrm{H},-\mathrm{OMe}), 4.25\left(\mathrm{br}, 2 \mathrm{H}, 2-\mathrm{CH}_{2}\right), 5.09(\mathrm{br}, 1 \mathrm{H}, 6-\mathrm{CH}), 5.72(\mathrm{br}, 1 \mathrm{H}, 7- \\
\mathrm{CH}), 6.71\left(\mathrm{br}, 1 \mathrm{H}, 4^{\prime \prime}-\mathrm{CH}\right), 6.76\left(\mathrm{br}, 1 \mathrm{H}, 4^{\prime}-\mathrm{CH}\right), 7.22\left(\mathrm{br}, 2 \mathrm{H}, 2^{\prime \prime}-\mathrm{NH}_{2}\right), 7.42(\mathrm{br}, \\
\left.1 \mathrm{H}, 3^{\prime}-\mathrm{CH}\right), 8.04\left(\mathrm{br}, 1 \mathrm{H}, 5^{\prime}-\mathrm{CH}\right), 9.57(\mathrm{br}, 1 \mathrm{H}, 7-\mathrm{NH}) .\end{array}$ \\
\hline
\end{tabular}

In contrast, to the results found in the case of Ceftiofur metal complexes where the antibacterial activities of most of the complexes were enhanced showing that they behave as better bactericides than the pure drug, it has been reported in the literature that for some cephalosporins like Cefoxitin and Cefpodizime, the activity is decreased on complexation. ${ }^{18,22}$ These results are consistent with the results found in the case of other cephalosporins like Cephalothin, Cephalexin, Ciprofloxacin, and Cefazolin, where the activities for the metal complexes are found to be either comparable or more than that of the parent cephalosporin. ${ }^{14,15,17,20}$ From these observations, it is very hard to infer the relationship between antibacterial activity and its chelation. However, till date, it is understood to be a function of electronic, steric as well as pharmacokinetic factors, with mechanistic routes. ${ }^{26}$ 
RASĀYAN $J$. Chem.

Vol. 11 | No. 4 |1715 - 1720| October - December | 2018

\section{CONCLUSION}

Ceftiofur complexes with metal ions of (1:1) ligand to metal stoichiometry have been prepared. The coordination to metal happens through the carboxylate and amidic carbonyl (CO) groups although the binding through $\beta$-lactamic carbonyl group cannot be ruled out in some complexes. The solubility of the metal complexes is drastically reduced on complexation. Except for $\mathrm{Zn}^{+2}$ complex which shows activity only in the case of Proteus vulgaris, the majority of the complexes show activity as better bactericides than Ceftiofur hydrochloride.

\section{ACKNOWLEDGMENT}

This research has not received any specific grant from funding agencies in the public or commercial sectors.

\section{REFERENCES}

1. R. E. Hornish, S. F. Kotarski, Curr. Top. Med. Chem.,2,717 (2002), DOI: $10.2174 / 1568026023393679$

2. D. R. Williams, The Metals of Life, London: Van Nostrand Reinhold, (1971).

3. J. R. J. Sorenson, J. Med. Chem.,19, 135 (1976), DOI: 10.1021/jm00223a024

4. D. H. Brown, W. E. Smith, J. W. Teape, J. Med. Chem.,23, 729 (1980), DOI: 10.1021/jm00181a006

5. J. R. J. Sorenson, Copper in The Environment, New York: Wiley-Interscience, (1981).

6. S. Jain, N. K. Jain, K. S. Pitre, J. Pharm. Biomed. Anal.,29, 795(2002), DOI: 10.1016/S07317085(02)00178-4

7. M. M. Correia doss Santos, V. Famila, M. L. S. Gonealvas, Anal.Biochem.,303, 111(2002), DOI: 10.1006/abio.2002.5580

8. S. Jain, N. K. Jain, K. S. Pitre, J. Pharm. Biomed. Anal., 31, 1035(2003), DOI: 10.1016/S07317085(02)00700-8

9. T. M. Develin, Text Book of Biochemistry with Clinical Correlations, $2^{\text {nd }}$ edn. Singapore: Wiley Medical Publication, (1986).

10. N. A. El-Maali, A. H. Osman, Aly AAM, Al-Hazmi, Bioelectrochem., 65, 95(2005), DOI: 10.1016/j.bioelechem.2004.09.002

11. A. H. Osman, Aly AAM, El-Maali, G.A.A.Al-Hazmi, Synth React Inorg Met-OrgChem,, 32, 1289 (2002), DOI: $10.1081 /$ SIM-120014306

12. A. L. Doadrio, A. Mayorga, R. Orenga, J. Braz.Chem. Soc.,13, 95(2002), DOI: 10.1590/S010350532002000100015

13. M. M. Ayad, A. A. Shalaby, H. E. Abdella, H. M. Elsaid, J. Pharm. Biomed. Anal., 18, 975(1999), DOI: $10.1016 / \mathrm{S} 0731-7085(98) 00106-\mathrm{X}$

14. J. R. Anacona, J. Serrano, J. Coord.Chem., 56, 313(2003), DOI: 10.1080/0095897031000069085

15. J. R. Anacona, I. Rodriguez, J. Coord. Chem., 57, 1263(2004), DOI: 10.1080/00958970410001721411

16. J. R. Anacona, I. Osorio, Trans. Met. Chem., 33, 517(2008), DOI: 10.1007/s11243-008-9074-y

17. J. R. Anacona, C. Toledo, Trans. Met. Chem., 26,228 (2001), DOI: 10.1023/A:1007154817081

18. J. R. Anacona, C. C. Gil, Trans. Met. Chem., 30, 605(2005), DOI: 10.1007/s11243-005-3847-3

19. J. R. Anacona, J. Estacio, Trans. Met. Chem., 31, 227(2006), DOI: 10.1007/s11243-005-6360-9

20. J. R. Anacona, P. Alvarej, Trans. Met. Chem., 27, 856(2002), DOI: 10.1023/A:1021376519769

21. J. R. Anacona, G. D. Silva, J. Chil.Chem.Soc.,50, 447(2005), DOI: 10.4067/S071797072005000200001.

22. H. A. Sayed, Y. Mrestani, H. N. Dietrich, G. Cornelia, H.H.N.Reinhard, J. Pharm. Pharmacol.,61, 1 (2009), DOI: 10.1211/jpp.61.06.0007.

23. L. M. Pascott, J. P. Harley, D. A. Klein, Microbiology, $6^{\text {th }}$ edn. McGraw Hill Publication, 2005.

24. J. R. Anacona, A. Rodriguez, Trans. Met. Chem., 30, 897(2005), DOI: 10.1007/s11243-005-6219-0

25. K. Nakamoto, Infrared and Raman Spectra of Inorganic and Coordination Compounds, $4^{\text {th }}$ edn. New York: John Wiley, 1986.

26. J. R. Anacona, F. Acosta, J. Coord.Chem., 59, 621(2005), DOI: 10.1080/00958970500393208

[RJC-4049/2018] 